\title{
Home Fires and Hearth: One's Place in this World and How Art Can Make a Difference
}

\section{Introduction}

Ties between land and human identity, culture and adaptation to the environment are undeniably complex: these connections are the core of how people define their home. One's place in the world, seemingly so straightforward, is actually a complex set of interrelationships that are, in part, selected and negotiated. In this paper I will examine through art the effects of cultural history and philosophy typified in indigenous peoples generally, and Maori in particular. Contemporary art and artefacts make visible the effects of multicultural differences. This is especially apparent in contested lands. Debated claims of ownership and entitlement have historically been the cause of many, if not most, wars: if we look to artists we have a chance to address conflict from a completely different - and ultimately hopeful - perspective.

Mary Modeen is an artist/printmaker who also works on art books, installations, and recently, on video and sound. She is also an academic of more than 25 years experience, residing in Scotland, where she is a Senior Lecturer in Fine Art and the Course Director for Art, Philosophy and Contemporary Practices at the Duncan of Jordanstone College of Art and Design, University of Dundee. 


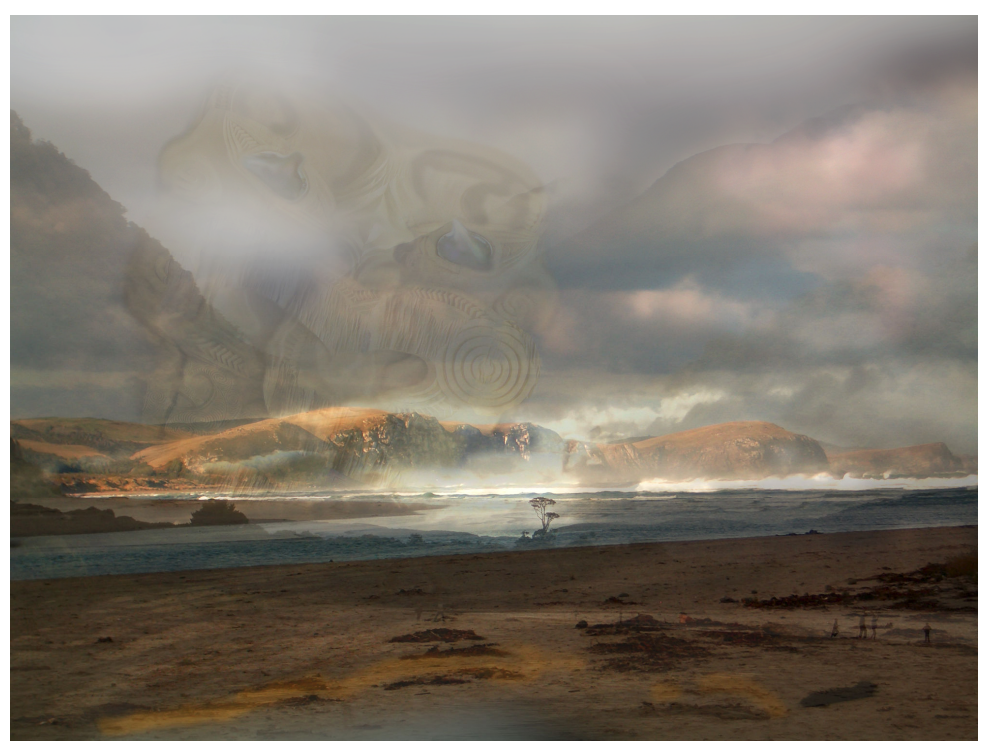

Māori descent is traced from spirit ancestors (wairua) and human ancestors (tipuna) whose spirits reside in the land: in this way, Māori identity is linked intrinsically with the land. Mary Modeen, (Where the River Meets the Sea), digital inkjet print on rag paper, 2007.

Within the scope of this paper, I will not be able to consider the most general questions about what constitutes indigenes, or how peoples living in urban or metropolitan centres have a slightly different perspective on their own cultures than people living in rural or regional locations. This will have to be a task for the future. However, what I will focus upon is the cultural history of Māori and how art might give us an insight into their identity and beliefs. I use Māori as a specific example throughout this paper but all indigenous peoples are implicit within the scope of this discussion. Indigenous peoples have a specific claim as a part of their identity to land, history and inheritance. But how does this claim coincide with those of others peoples whose families are perhaps immigrants; or who travelled, homesteaded and settled a new homeland within the last hundred years or two; 
or even of those who are of mixed cultures or uncertain descent?

Being born human has its own claim to a place to belong. So we would all like to believe. But does it? In the eyes of enemies (and for this word, read 'competitors') any claim to a place is unacceptable. Hence, the genocides which have so appalled us - recently, Jews in WWII, Tutsis in Rwanda, native Albanians in Kosovo, and, in the 19th century, native Americans in the expansion westwards, Māori from their traditional lands, all native Tasmanians ... sadly, the list goes on and on.

The term 'genocide' was coined by Raphael Lemkin (19001959) in 1943. It comes from the Greek genos for family, tribe or race and occide for massacre. It is the most extreme form of denial - denial of basic human rights to exist; denial of the right to have a place on this planet; denial of another human's entire being or shared humanity - no matter what their beliefs, their origins, or their physical being. It is intolerance taken to its most extreme form. But if we accept that there is a place for every person, whatever the circumstances of birth, beliefs or race, then how we do begin to sort out the complexities of multiple and conflicting claims? How do we learn tolerance and peaceful co-habitation in lands where philosophies and cultures vary radically?

\section{Ownership versus occupation}

In order to answer this question, let us return briefly to the question of claims on land as the site for making homes and living from the earth's sustenance. On what basis are claims made? In Aotearoa/New Zealand, for example, the indigenous Māori stake their claim on spiritual connections with the land; on traditional patterns of life, which include hunting, gathering, fishing and home-making. This is not different from other peoples around the world, I hasten to add: in patterns that are echoed throughout native populations, the building of fires to cook food and warm family members is exactly the same. Hearth and home seem synonymous; most humans accept the hearth as the heart of the home. 
After the Treaty of Waitangi in 1840, in order to prove what the Europeans could sanction as 'ownership by custom or long-term occupation', Māori were forced to prove that they actually occupied land. They did this by demonstrating home fires burning, as well as by hunting birds, by crops, by trapping and fishing, etc. Ahi kā (the home fires) as a focal point for contested rights to the land came to be both metaphorical and physical. Children of Māori parents returning to traditional lands could claim that their fires reestablished the pattern of occupation. But after three generations, from original inhabitant to grandchildren, physical absence from the land meant that the home fires had grown cold (ahi mātaotao), and that claim on the land was open.

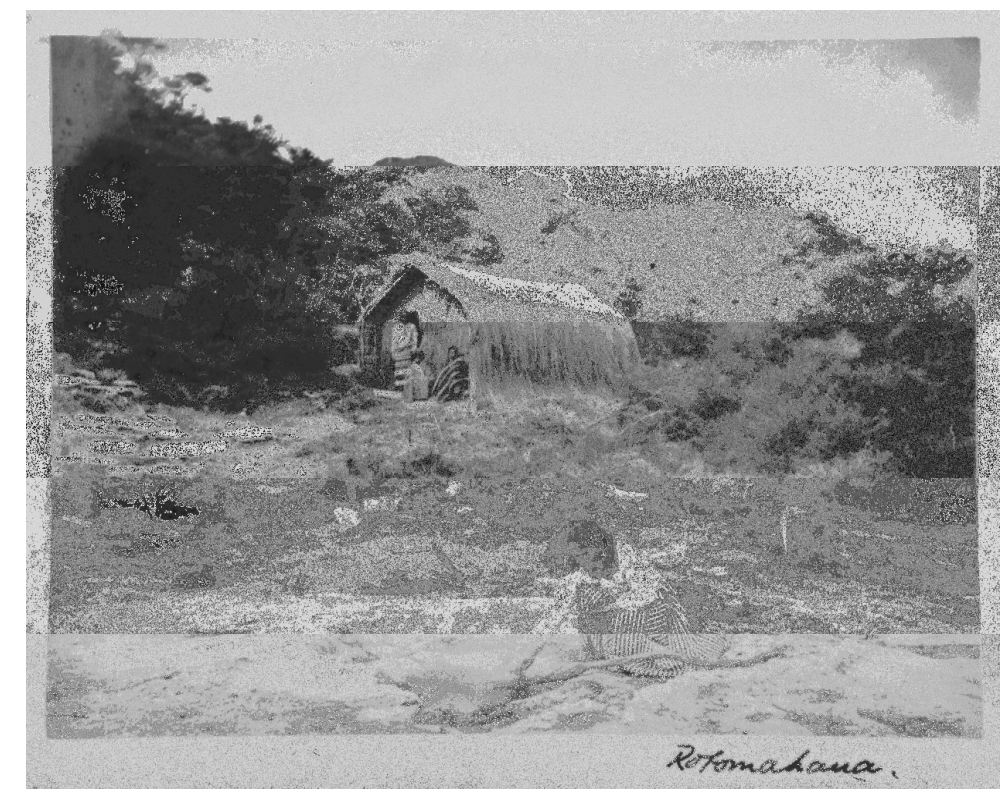

Rotomahana, anon. Ca. 1870's. From the Hocken Collections, (C) Hocken Library, University of Otago, Dunedin, New Zealand. A photograph of a Māori woman tending her ahi kā, with a clearly visible domestic structure and family in the background. 
Philosophically, of course, Māori did not believe in land ownership. They were (and are) very passionate about responsibilities of stewardship and guardianship of the land, plants and animals. But they feel themselves to be intrinsically a part of the land: ownership is a strange concept when one is part of the thing to 'own'. In a nutshell then, we have an example of an indigenous claim to land based upon philosophical and spiritual connections pitted against Pākehā settlers' expansion and confiscation. The result of this is played out in land courts to this very day, and is - in essence the conflict of two very opposed world views.

\section{Contested claims}

In the case of conflict one might ask, is one side right and the other wrong? This is usually a far too simplistic and unhelpful version of understanding, especially when human rights are involved. Again, one might ask, 'Does one group have the right to remain on the land and exploit nature's resources to the exclusion of the other group? And by whose philosophy and belief system does one party 'win' the claim?' This is the crux of the problem as I see it. Two cultures, philosophically opposed, have overlapping but significantly different claims. Without wishing to presume on the Aotearoa/New Zealand judiciary, I suggest that a general overview is useful.

First, let us consider the nature of the contested claims from high above, as if on an imaginary mountaintop. The distant perspective gives us the chance to see the whole topic in miniature. A debate has as its central character two positions in opposition. Typically the questions under debate are not so much perceived as right or wrong (in an absolute moral sense, although ethics are often included in reflective discussions) but as an opportunity to air full considerations and information. In land claims, the debate is extended to necessarily include cultural assumptions and values. In other words, basic philosophy and world views are incorporated in the formation of the laws by which land courts deliberate claims and pronounce judgments. This seems obvious from 
this height, but not so obvious when we stand at ground level witnessing a debate about ownership by a people whose tradition did not countenance ownership but rather kinship with the land.

Thinking further about how laws are made, the notion of proportional demographics of a population might be said to hold sway; but it was not a case of 'majority rules' in South Africa, for example, until very recently. People in New Zealand who identify themselves as Māori, either in full or in part, constitute roughly $16-17 \%$ of the population today. But they were the majority population in the $19^{\text {th }} \mathrm{C}$ when they had lands continually confiscated and appropriated from them, whether through treaty, 'sale' or encroachment. As have had the Native Americans, in ongoing confiscations of reservation lands, and First Nation Canadians, and so on.

If laws are not then determined by majority of population, how does one philosophy come to dominate another? Two answers seem apparent. One is that in the history of humankind dominance has been asserted through violence: 'might makes right'. The stronger the warriors, the larger the force, the more superior the weapons, the more likely it was that lands could be won. And, as a corollary, that the conquered nations' beliefs are either ignored or misunderstood. To place too high an importance on the beliefs of one's enemies is to run the risk of granting them equal status as human beings. Intolerance and denial of human rights is based in ignorance. Dismiss enemies as 'savages' and the denial of their rights seems more palatable, or even in their best interest'.

\section{Universal need}

If we put aside all cultural differences for a moment, there is one thing that unites all humans. It is precisely the need for a place to call home and an identity secure enough to live in harmony with the environment. This is a universal human need. Safety, security, a place to build shelter, and land upon which to grow food or to hunt, fish and gather is the physical site of what we call home. Once immediate needs are met, 
humans historically have found the means to study their environment, to learn from nature, and to adapt with remarkable efficiency. Very quickly the human dwellers upon the land come to identify themselves as a part of the land that sustains them. In every indigenous culture on this planet belief systems profoundly link traditional cosmogony with the numinous spirits inherent in the natural environment.

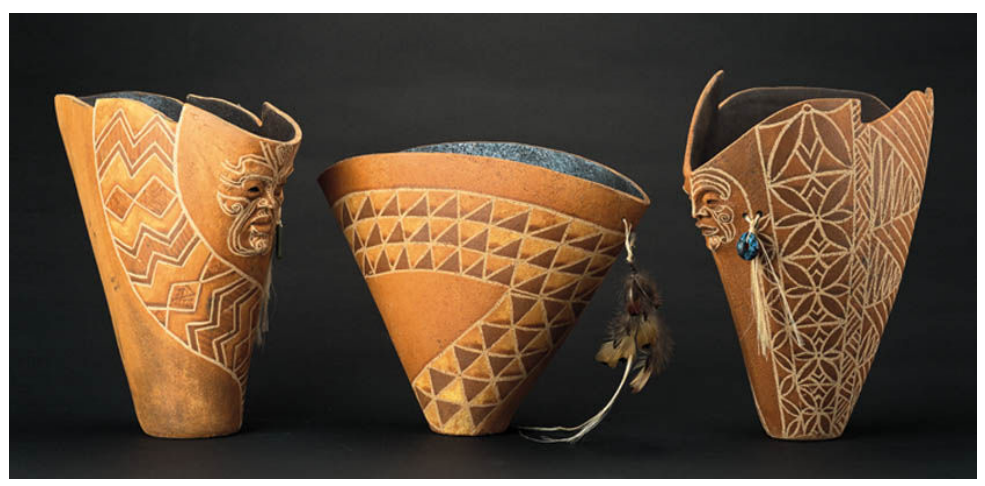

Colleen Waata Urlich, (1939- ) ceramic vessels with flax and feathers. All materials in this work are taken from the immediate environment. The faces are of wairua (spirits).

It is the perception among these various peoples that the unseen is as important as the seen, and that the harmony achieved in a pattern of life is due to a respect for the land as a part of and not distinct from the human occupants.

The philosopher Martin Heidegger (1889-1976) considered these ideas through language: in its original meanings in Old English and High German, bauen (building) meant 'to dwell'. Dwelling meant more than simply residing, staying somewhere - it meant to work, to live, in short, to be in this world. He writes, 'To be a human being means to be on the earth as a mortal. It means to dwell.'... and then continues:

... we are dwellers. But in what does the nature of dwelling consist? Let us listen once more to what language says to us. The Old Saxon wuon, the Gothic wunian, like the word bauen, mean to remain, to stay in a place. But the Gothic wunian says 
more distinctly how this remaining is experienced. Wunian means: to be at peace, to be brought to peace, to remain in peace... The fundamental character of dwelling is this sparing and preserving. (Heidegger 1971: 144-147. Author's italics.)

Dwelling, then, for Heidegger is inhabiting; it is being in a place on this earth, actively engaged in preserving the place, but also at peace, living in harmony with the land and other people. In later writing he links this dwelling even more closely with thinking: dwelling (staying, being) is thinking, taking up residence within thought and the imagination.

\section{How artists address this: identity, homeland, environment}

Now, finally, we have arrived at the point where we must consider the role of artists in this link between cultural identity and the land. The language of images and objects appealing as much to the intuitive as to the intellectual, may be based equally in critical commentary and in aesthetic transformation. 'Truth' in art means truth to an individual's experience, to their whole understanding as it informs the making processes. Deep knowledge, and a wellspring of precognisant understanding, allow artists to find visual imagery that bypasses rational and verbal analysis. Art may speak to the deepest, innermost parts of human imagination, and in doing so provide the essential bridge which links one person's experience with another's.

Art, defined in its broadest sense, includes weaving, carving, ceramics, performance, fibre art and textiles, photography and film, and is made by local people in their own traditions, referencing their immediate environment. It cannot help but display distinctive differences, speaking in the visual equivalent of 'local accents' with the benefit of actual experience. For example, Māori traditional moko (traditional tattoo) and whakairo (traditional woodcarving) are imbued with many of the visual qualities shared across Pacific island cultures. Essential to the Polynesian experience is the feature of water references as well as those of fishing, birds, and ferns. 
Fish hooks, woven patterns, and intricate interlocking serpentine forms abound. Human figures are transformed into faces or heads supported by stylised torsos; male figures are often warriors or protectively aggressive.

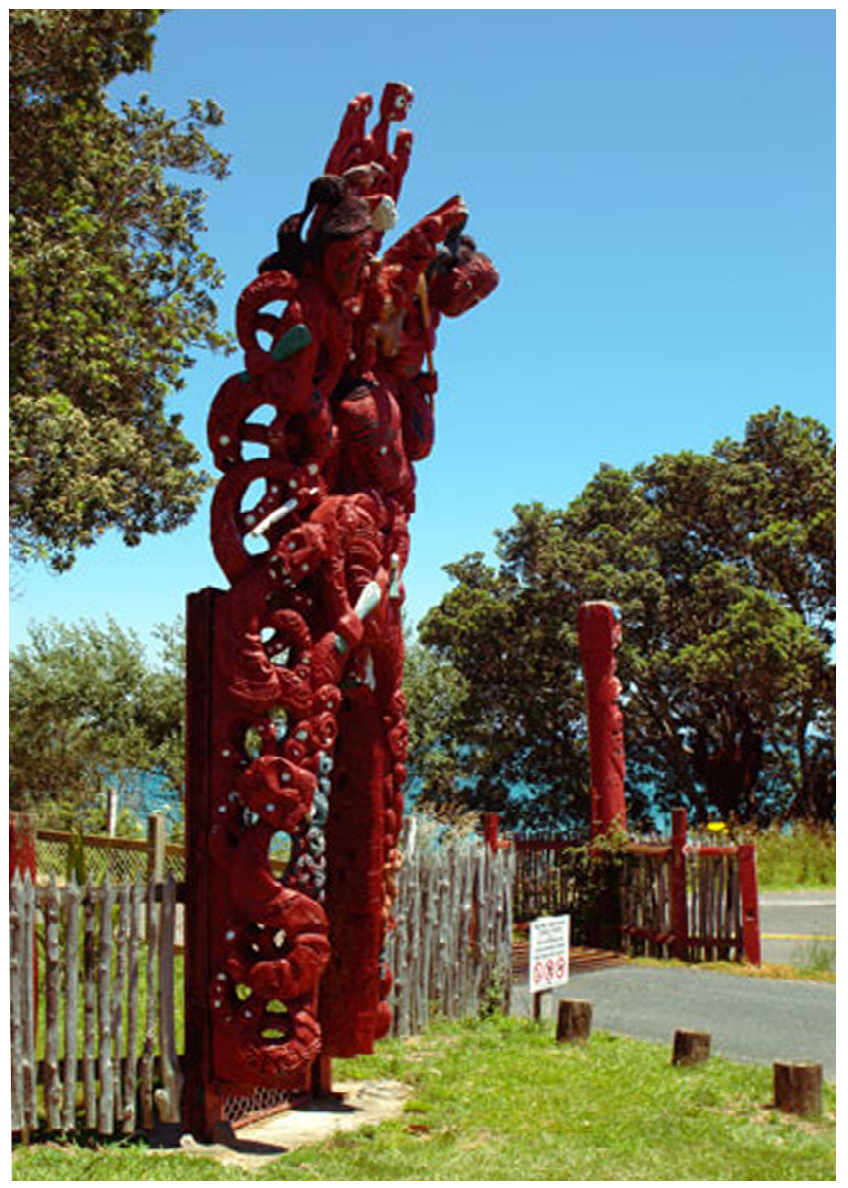

Whakairo (literally, decoration), traditional wood carving in the entrance of a marae. 'The function of whakairo is to create understandings that exist within Māori culture and to help organise social behaviour' (Harrison et al. 2004: 116). 
Female figures, while less often represented, tend to be linked to fertility or mythic icons of motherhood. This Māori art is distinctive in its patterning, but shares visual similarities with traditional carvings from half a world away, as in the Pictish standing stones of Scotland.

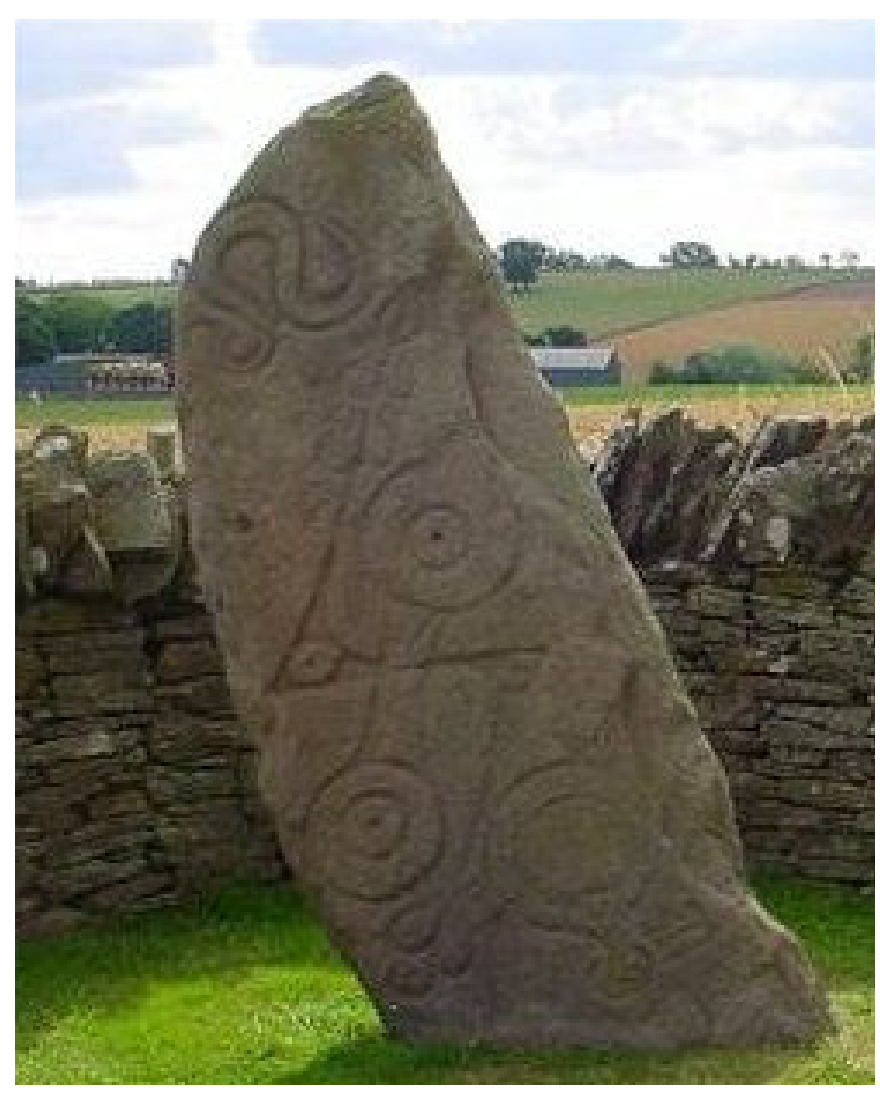

The so-called Serpent Stone, Class1 Pictish Standing stone at Aberlemno, Angus, Scotland. ${ }^{1}$

Many cultural anthropologists profess that the making of art serves several sociological and psychological functions (Hatcher 2003: 103-112). Among these are the 'playing out' of 
desires for mastery (i.e. over death, over foes, over dangerous animals, etc.); or the 'working out' of problems (either personal or communal, things that are troubling are confronted, conflicts resolved); the representation of significant stories or history in visual symbols; or the deliberate encryption of knowledge in visual 'codes'. Art linked to ritual ceremonies or curative processes is included in this functionality. But most people who study art and artefacts within a cross-cultural context agree that the aesthetic qualities of a creative work are essential in considering meaning. By this, I mean that the qualities of beauty, the appeal of the actual materials used, the attention to the physical appearance and making of the art, and most of all the link between the unseen hand of the artist as it is contained in the art as it suggests a power or mystery - all this is intrinsic to the work of art. In considering and interpreting meaning, it is the art that begins to stand for the whole culture.

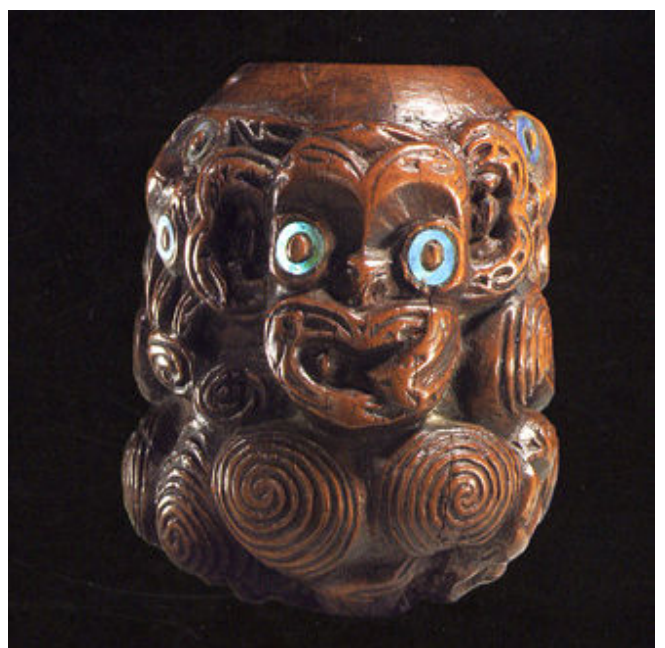

Carved Maori pigment holder, rimu wood with paua shell inlay, ca. 1880.

In reflecting on this last statement, let us return to Māori facial tattoos; moko are a part of Māori culture because Māori 
do not hesitate to link themselves to the past, to their families, or to the land. In fact, it is precisely this deeply felt connection - in all the senses of land, society and family - that is distinctive about Māori whakapapa (genealogy and personal legacy), lines of descent with which I began this discussion. Traditionally one could see from moko at a glance who the individual's mother's family and father's family were, and how this individual was valued in her or his community: a teacher; an artist; a chief. Distinctiveness as an individual is visibly preserved while simultaneously reinforcing a cultural context; the individual's place - in the community, in the land, in the world - is established for all to see.

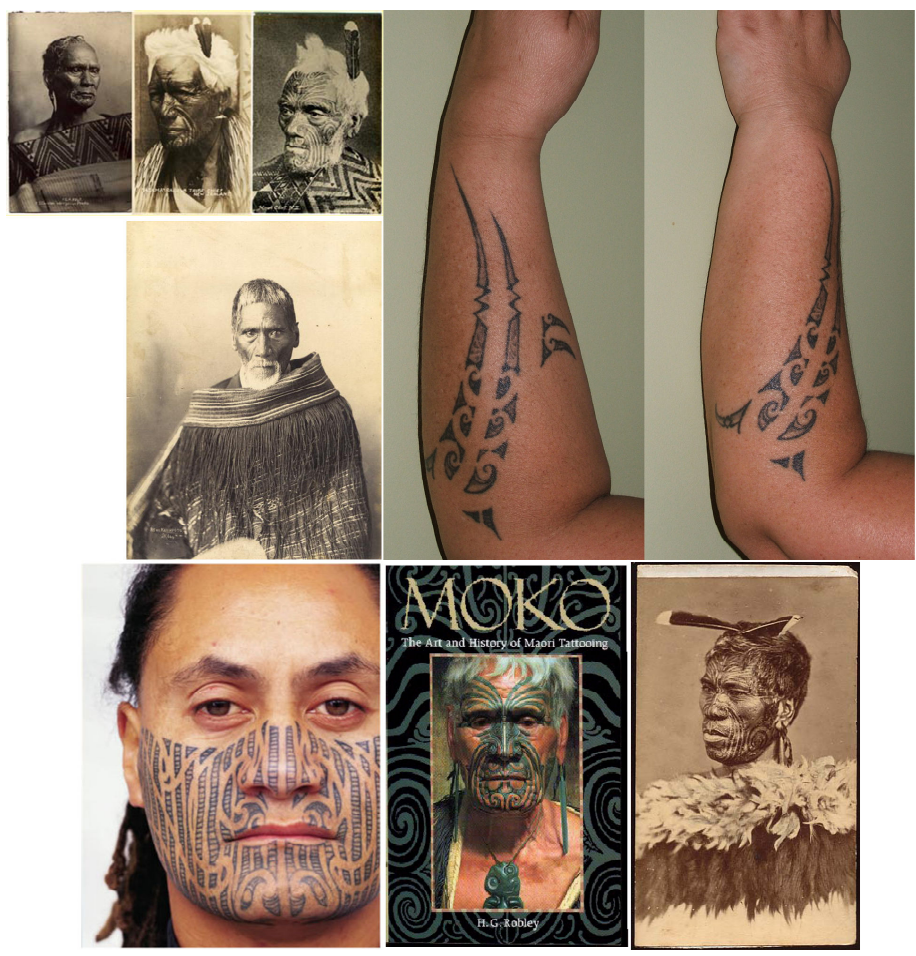

Various examples of moko, both historic and contemporary. 
To an outsider, this body art is odd, curious, or even a bit frightening. Not knowing its significance makes the Māori strange, Other. How can a tattooed face 'fit in' with whites?

To answer this question is to begin to understand the potential of art in negotiating multicultural understanding. Because the answer is, precisely, that a moko bearer will always be different, will always stand apart as not like everyone else.

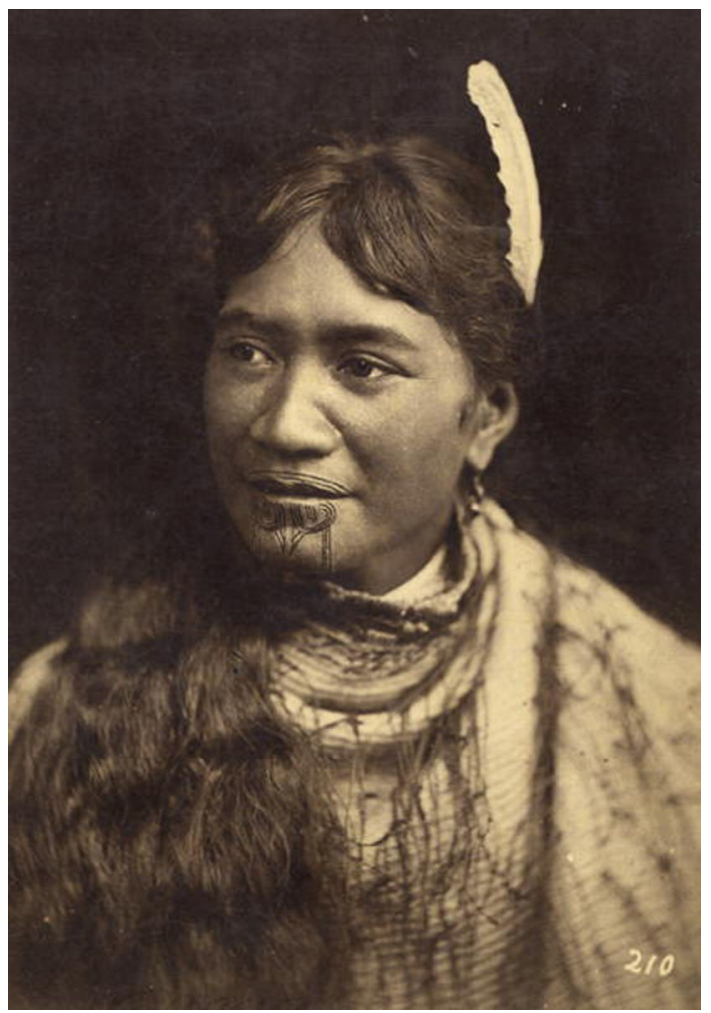

Women have traditional moko on their lips and chin rather than over the whole face. Elizabeth Pulman, (1836-1900), Portrait, c.1875 (albumen print), (CBridgman Library Archive.

'Fitting in' doesn't mean being the same. Distinctive multicultural differences are exactly that: different. And viva la 
différence, I say. We have only to look at the blandness of a worldwide uniformity, to contemplate the unrelenting tedium of homogeneity on a global scale. And thereby, we quickly understand just how fortunate humanity is to have so many variations on a theme. Visual arts, transcending verbal languages, may be one of the very best ways to see these differences manifested.

This is not to treat the subject as an ethnographic curiosity. Although attitudes change over time, it is distressing to find multicultural differences seen as curios in ethnographic collections. Māori heads were collected in the $19^{\text {th }}$ century and brought back to museums in America and Europe. They were usually smoked to preserve the tattooed skin and actual human heads have been presented for the last hundred and fifty years as anthropological specimens. ${ }^{2}$

\section{How art is read}

Undeniably, art has power. It has the power of suggestion - of evoking an interpretive response on many levels. On the first level is that of representation. 'What' is it that is being represented? A human? A snake? A fish? On the next level is the significance of this representation: not just a fish, but a fish presented in a manner completely dissimilar from, say, Inuit fish, or Celtic fish. Thirdly is the cultural attachment of significance in these readings: is it a symbol for a Christian? Is it a clan totem? Is it a wairua (god/spirit) in fish form? And finally, the last level of significance might be considered to be that of transformation, or mystery and an appeal to the collective unconscious, as Jung would have it. Shared human experience means psychological and cognitive understanding across language barriers: we need not speak Māori in order to feel the power of this fish carving. 


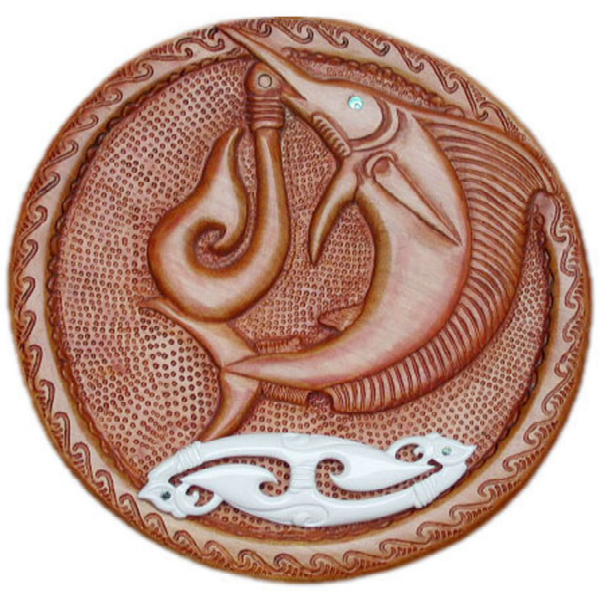

Manaia is the spiritual guardian over air, land and water, often depicted with a seahorse type of shape. Joe Katoa, Marlin and Manaia, carved rimu wood and beef bone, $28.5 \mathrm{cms}$ diameter, (C)the artist.

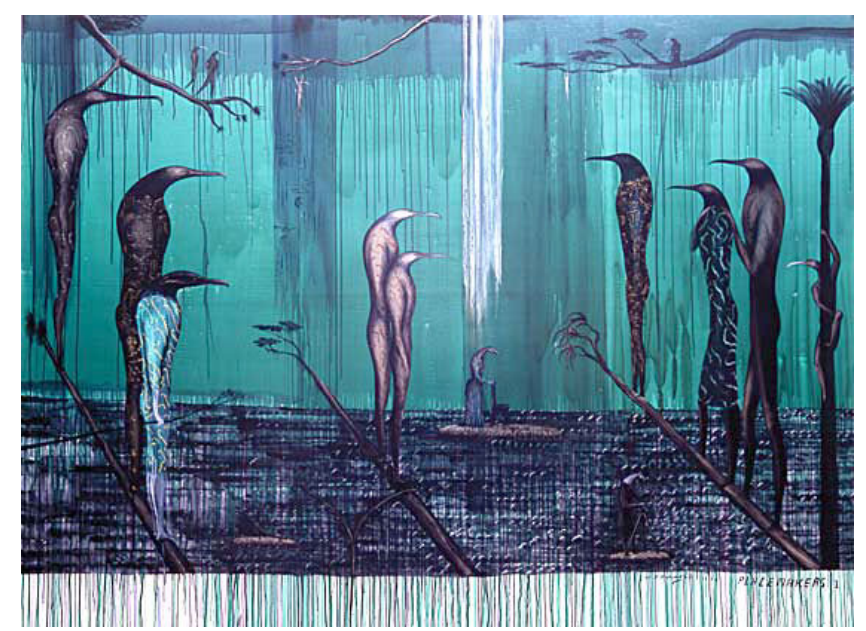

Bill Hammond (1947- ), Placemakers I, Oil on Canvas, 1996.

In a similar manner, the contemporary New Zealand artist Bill Hammond uses birds. ${ }^{3}$ He relies upon exactly the same

Te Kaharoa, vol. 2, 2009, ISSN 1178-6035 
traditions of understanding that appeal to our consciousness and unconsciousness, equally. Rationally, we look at this and see a painting of birds in unlikely poses. Irrationally but with deep understanding, we look at this and see a commentary on society and individuals, on relationships, and on an ineffable atmospheric quality in a wet and melancholic environment. The birds are bird-people, birds and people, standing forlornly in pairs or individually, isolated in the wetlands. Even the serpent that wraps around the trees is beaked. These are characters that inhabit the place, and according to the title, that make the place in doing so.

Culture is not just related to things in the past. One of the most salient aspects of contemporary art is that it is a vital and ongoing process of interpretation. It is evidence - if such were needed - that culture is not static, it is dynamic and constantly changing. Elements of cultural history do, of course, factor into the making of art, but art is a facet of contemporary culture.

Let us look at an example of this: Ralph Hotere is an artist who is both Māori and European trained. ${ }^{4}$ He works from two separate frames of cultural referencing - one Māori, and one Catholic. But in fact, he speaks in the language of contemporary art, and as such is comprehensible to any viewer.

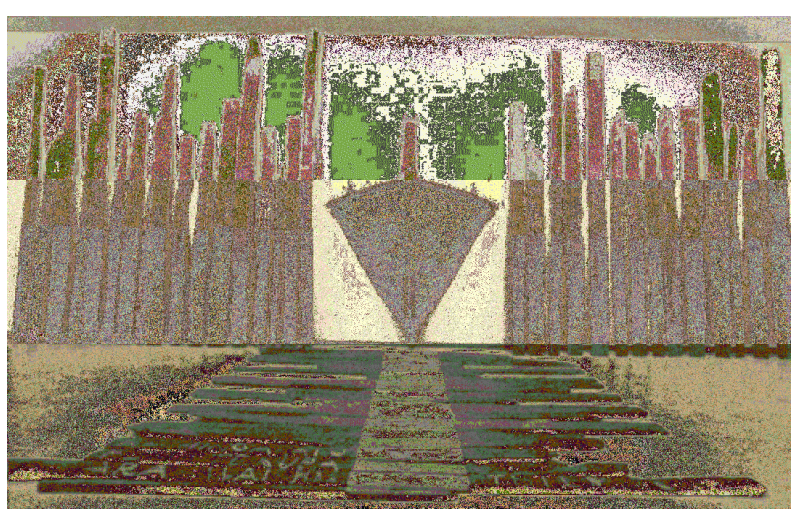

Ralph Hotere, The Black Phoenix, installation with wood and metal, (1984-88). 
In this art installation entitled The Black Phoenix, burnt wood and metal are laid out in regular patterns on the floor and leaning against the wall. There are bare light areas that read across each piece, but the dark colour is the dominant tone. Black is heavy. It weighs us down. The weight is countered by a pointed form in the middle, triangular and resting on its point. A bird in flight? A shield? An arrow? Each has possible readings of cultural and lyric significance. Regularity of visual rhythms suggests fencing, treelines, or even more grimly, bodies laid out in rows. The scratching and markings on the wood are partially legible, words and fragments of words compete with illegible marks. The Phoenix in the title is compelling us to wonder: has it been burned beyond recognition? Is it about to rise from this charred pile? Is redemption from a scarred past possible? In Māori readings, this scarred past is definitely one to rise from, to continue, renewed. But Catholic readings might suggest parallels with Christ rising again. In both, the question of ascension is oblique, encoded in the materials, lyrically suggested but weighed down by the material heaviness. Even in this pile of wood and scrap there is beauty, but melancholy as well.

Artists offer us all a lesson in the way we use our lifetime to achieve something. Look at any artist working and you will usually see someone absorbed in his or her work, often almost obsessed with the process of physically realising his or her visual ideas. Some of what they make is utterly their own, but some echoes a tradition of making that has been painstakingly learned and refined. In the case of Māori weaving, the tradition of raranga has been handed down for generations. Young women (traditionally, since males were encouraged to take up wood carving) would learn their craft in the house of weavers. As an initiate, they would have wooden sticks forcing their mouths open while they heard the wisdom of instruction. This had two functions: one was to open the mouth to receive the 'breath of wisdom' to enter their bodies. But not by chance it also prevented the young women from speaking or interrupting the receipt of knowledge.

Learning that arises from unspoken teaching is often visually conveyed. Mātauranga (knowledge) has a special 
significance to Māori: it is knowledge that is imbued with spiritual as well as practical wisdom that is embedded in the making process.

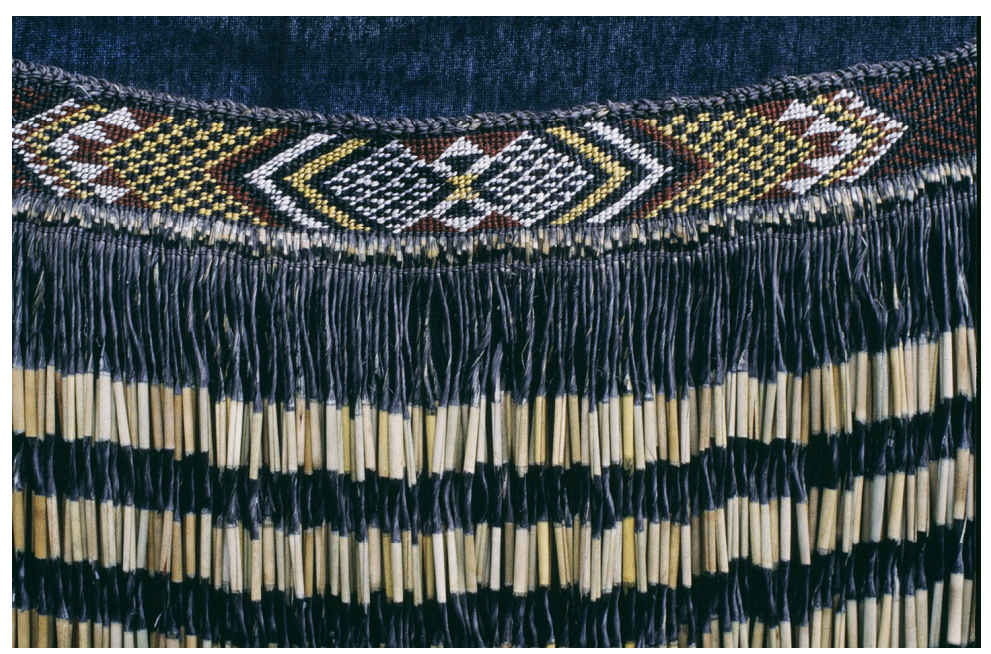

Kahutoi Te Kanawa, Piupiu, harakeke.

Kahutoi Te Kanawa made this piupiu (traditional Māori flax skirt, worn in a shorter length for men and longer for women, especially in dance performances). She combines tradition and the knowledge of generations with her own creative inspirations for making choices in patterns, colour and designs. As the daughter and granddaughter of famous Māori weavers ${ }^{5}$ she respects and upholds the tradition of raranga, but as a contemporary artist she is also very much her own woman when it comes to the aesthetic sensitivity and skill with which she makes her art. As with any artist who chooses to work in a classical tradition, the strictures of the form allow for freedom of aesthetic invention. 


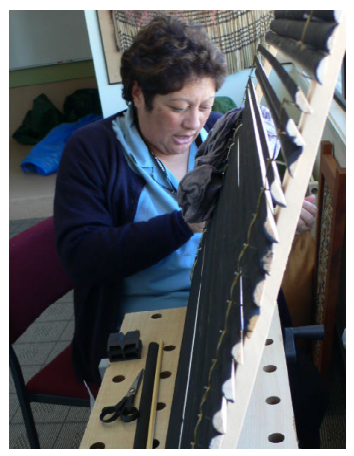

Kahutoi Te Kanawa at work, 2007.

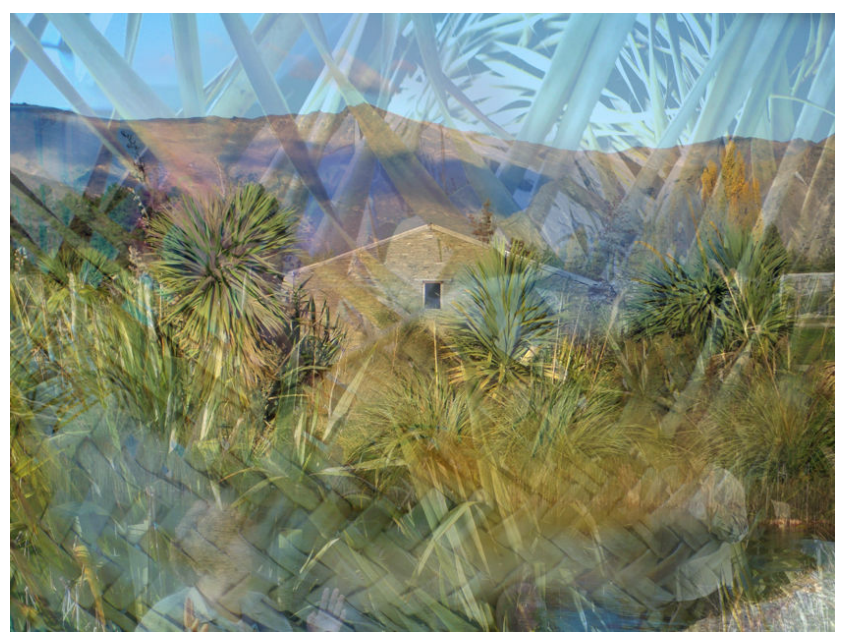

Mary Modeen, Mātauranga (Knowledge), digital inkjet print on rag paper, 2007.

In my art I responded to the cultural tradition of weaving as taught by Kahutoi Te Kanawa. She teaches every aspect of the traditional knowledge, not just the fabrication skills. She teaches about the environment, where the harakeke plants grow and how they are cared for, when is the best time to harvest and how to do so without damaging the parent plant, and how to say in Māori a karakia (blessing) of thanks for the 
gift of harvested leaves. As an artist I intuitively understood her description of moments of understanding that came as epiphanies in the long hours of weaving: at some point the maker transcends the patterning of under and over and realises that she is constructing a fabric of knowledge, assembling something that didn't exist before. Much more than warp and weft, she sees the wholeness of vision assembling slowly before her eyes.

Art exists; once made, it is out of the artist's control how it is interpreted and politically used or abused. In a material culture, for example, it is possible to see these works of art as commodities to be sold or bartered in the marketplace. The desire for beautiful objects, the attention to handmade things, and the aesthetic pleasure in looking at these creates and sustains a certain market. Beyond that, artwork that is exhibited in public venues begins to address larger questions of content and interpretation: critics, writers, curators and a naturally curious viewing public reflect on cultural readings of the work. It is at this point that art has the potential to effect positive and forceful change: it can challenge assumptions, it can undermine prejudice, it can offer hopeful and, yes, humanistic visions for the peaceful resolution of conflicts.

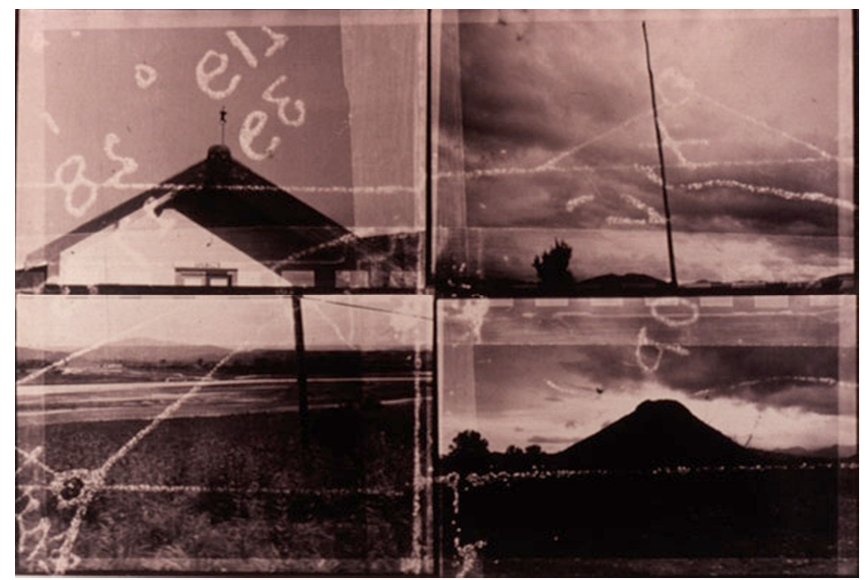

Natalie Robertson, The Surveyor's Fieldbooks 1, 1996. 
The artist Natalie Robertson is of Māori Ngāti Porou descent. She is a trustee and kaitiaki (guardian) of her tribal lands, a role she inherited from her grandfather. And as such, she is also an artist deeply committed to the preservation of land, to the significance of cultural inheritance, and to the role of art as a means to effect change in contemporary consciousness. Her work pictured here above is part of an ongoing series of manipulated photographs ${ }^{6}$ taken from the land and from roadsides. Often she includes road signs, map markings and evidence of journeys across Aotearoa/New Zealand. This work is evocative of memories of place, suggestive of the overlay of time past with present experience. Her markings are personal, cryptic, partly layering her own hand across the image, but suggesting alternative experience as well. Road signs are incontrovertible as directions, but where do they lead? The names of places, and the direction by which we move, take on larger cultural significance in her art, subtly confounding what seems at first to be the most straightforward of conventions.

In the work of artists discussed here, and as I aim for in my own art, there resides the meaning that defies purely rational explanation. The power of visual art lies in its appeal to the imagination of the viewer. Art has the power to address complex issues, as in here above where culture, philosophy, history, psychology and geography intersect. Art has the power of showing cultural difference, of visually celebrating difference in ways that seem more human and often less frightening than other forms of communication. Above all, art has the power of hopeful re-imagining. And thereby, it can stretch our thinking, to pose possibilities for shared experience and new discourse that in turn opens the way for peaceful resolutions of contested lands and conflicting cultures. 


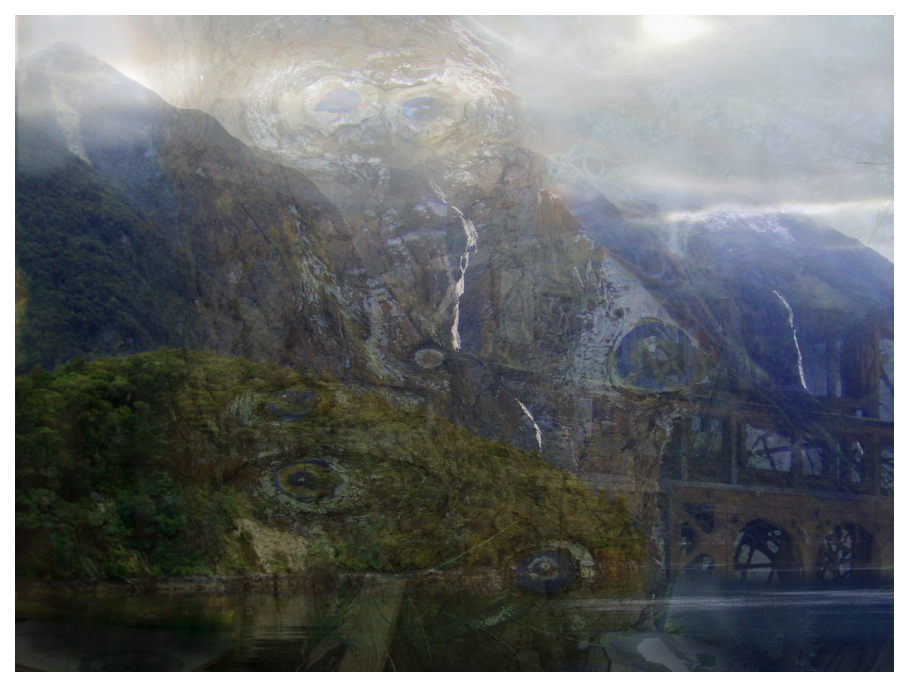

Mary Modeen, Te Wairua o te Maunga (The Spirit of the Mountain), digital inkjet print, 2007.

\section{Notes}

Markings on this stone include a serpent at the top, a 'double- $Z$ rod', and a 'mirror and comb' image near the base. Little is known of the Pictish culture other than the fact that they were the indigenous peoples of Scotland from around the fourth to ninth centuries. Most of the standing stones were carved with incised images of animals and these more inscrutable markings in the $6^{\text {th }}$ and $7^{\text {th }}$ centuries AD. By the eighth and ninth centuries, they were converting to Christianity.

2 The Field Museum in Chicago and Kelvingrove Museum in Glasgow, Scotland have both returned Maori heads to their home clans in Aotearoa within the last five years.

3 In Maori culture, birds are the intermediaries of humans and atua (gods).

4 Hone Papita Raukura (Ralph) Hotere, b. 1931 in Mitimiti, Northland, Aotearoa/New Zealand. Educated in London at the Central School of Art ('61) and travelled in France for two years, returning to Aotearoa/New Zealand in 1965. Among his most famous series are the Black Paintings.

5 Her mother is Diggeress Te Kanawa, (b.1920) and her grandmother was Dame Rangimarie Hetet (1892-1995). Both are internationally famous for their skills as traditional weavers.

6 Manipulated in the sense that this image was created in the darkroom with two layers--marked acetate and a photographic negative. 